\title{
Characterization of lethal factor binding and cell receptor binding domains of protective antigen of Bacillus anthracis using monoclonal antibodies
}

\author{
Stephen F. Little, ${ }^{1}$ Jeanne M. Novak, ${ }^{1} \dagger$ John R. Lowe, ${ }^{1}$ \\ Stephen H. Leppla, ${ }^{1} \ddagger$ Yogendra Singh, ${ }^{2} \S$ Kurt R. Klimpel, ${ }^{2}$ \\ Burton C. Lidgerding ${ }^{1} \|$ and Arthur M. Friedlander ${ }^{1}$ \\ Author for correspondence: Stephen F. Little. Tel: +1 301619 4914. Fax: +1 3016192152.
e-mail: steve_little@fftdetrck-ccmail.army.mil
}

1 US Army Medical Research Institute of Infectious Diseases, Fort Detrick, Frederick, MD 21702-5011, USA

2 Laboratory of Microbial Ecology, National Institute of Dental Research, Bethesda, MD 20892, USA

\begin{abstract}
Lethal toxin from Bacillus anthracis is composed of protective antigen (PA) and lethal factor (LF). Anti-PA mAbs that neutralized lethal toxin activity, either in vivo or in vitro, identified three non-overlapping antigenic regions on PA. Two distinct antigenic regions were recognized by the four $\mathrm{mAbs}$ that neutralized lethal toxin activity by inhibiting the binding of ${ }^{125}$ I-LF to cell-bound PA. Mapping showed that one mAb, $1 \mathrm{~GB}_{\text {paG3}}$ recognized an epitope on a $17 \mathrm{kDa}$ fragment located between amino acid residues Ser-168 and Phe-314. The three other mAbs, 2D3 ${ }_{\mathrm{PA}}, 2 \mathrm{D} 5_{\mathrm{PA}}$ and $10 \mathrm{D2} \mathrm{PA}_{\mathrm{PA}}$ recognized an epitope between amino acids Ile-581 and Asn-601. A single antigenic region was recognized by the three $\mathrm{mAbs}, 3 \mathrm{~B} \mathrm{PAA}_{\mathrm{PA}^{\prime}} 14 \mathrm{~B} 7_{\mathrm{PA}}$ and $10 \mathrm{E} 10_{\mathrm{PA} 63}$, that inhibited binding of ${ }^{125} \mathrm{I}-\mathrm{PA}$ to cells. This region was located between amino acids Asp-671 and lle-721. These results confirm previously defined functional domains of PA and suggest that LF may interact with two different sites on PA to form lethal toxin.
\end{abstract}

Keywords: Bacillus anthracis, protective antigen, epitope mapping

\section{INTRODUCTION}

Bacillus anthracis produces two protein exotoxins. Protective antigen (PA), combined with either lethal factor (LF) or oedema factor (EF), constitutes lethal toxin or oedema toxin, respectively (Beall et al., 1962; Stanley \& Smith, 1961). After PA ( $83 \mathrm{kDa})$ binds to a cellular receptor (Escuyer \& Collier, 1991), cleavage occurs at a trypsin-sensitive site localized to amino acid residues 164Arg-Lys-Lys-Arg-167 (Leppla et al., 1987; Singh et al., 1989). Proteolysis releases a $20 \mathrm{kDa}, \mathrm{N}$-terminal fragment (PA20), exposing a binding site for either LF or EF on the

\footnotetext{
†Present address: Division of Vaccines and Related Products Applications, FDA, 1401 Rockville Pike, Rockville, MD 20850-1448, USA.

$\ddagger$ Present address: Laboratory of Microbial Ecology, National Institute of Dental Research, Bethesda, MD 20892, USA.

\Present address: Centre for Biochemical Technology, Mall Road, Near Jubilee Hall, Delhi 110007, india.

\| Present address: Shepherd College, Shepherdstown, WV 25443, USA

Abbreviations: EF, oedema factor; HBSS, Hanks' balanced salt solution; LF, lethal factor; $P A$, protective antigen; T-PA, trypsin-treated PA; Ch-PA chymotrypsin-treated PA; Ch/T-PA, chymotrypsin/trypsin-treated PA.
}

receptor-bound, $63 \mathrm{kDa}$, C-terminal fragment, PA63 (Leppla et al., 1987, 1990; Novak et al., 1992). The toxin complex enters the cell by receptor-mediated endocytosis, and LF and EF are thought to be transported into the cytosol (Friedlander, 1986; Gordon et al., 1988). Recently, Milne et al. (1994) showed that PA63 forms heptameric oligomers, postulated as functioning in the translocation event. Lethal toxin causes severe pulmonary oedema and death in susceptible animals (Beall et al., 1962; Fish et al., 1968; Stanley \& Smith, 1961), and is rapidly cytolytic for macrophages in vitro (Friedlander, 1986). LF has recently been reported to exhibit homology to zinc metalloendopeptidases (Klimpel et al., 1994; Kochi et al., 1994). Oedema toxin causes oedematous lesions (Fish et al., 1968; Stanley \& Smith, 1961) attributed to the calmodulin-dependent adenylate cyclase activity of EF (Leppla, 1982). Based upon the model, PA thus contains domains involved in binding to cell receptors, binding of either catalytic moiety LF or EF, and translocating the toxin effector molecule into the cytoplasm (Leppla, 1991).

This work compares the ability of $\mathrm{mAbs}$ produced against PA to neutralize lethal toxin activity with their ability to inhibit binding of PA to cells and of LF to cell-bound PA. 
$\mathrm{mAbs}$ which effected these two binding interactions were mapped to three different regions on PA.

\section{METHODS}

B. anthracis antigens. PA and LF were purified as previously described (Leppla, 1988).

Generation and purification of proteolytic fragments of PA. PA63 and PA20 (Fig. 1) were prepared by limited digestion of PA with trypsin and separation of fragments by FPLC on MonoQ resin (Pharmacia-LKB) (Bhatnagar et al., 1989) using $20 \mathrm{mM}$ ethanolamine, $\mathrm{pH} 9 \cdot 5$. Fragments were dialysed against $10 \mathrm{mM}$ CHES buffer, $\mathrm{pH} 9 \cdot 5$, and stored at $-70^{\circ} \mathrm{C}$.

PA fragments of $47 \mathrm{kDa}$ (PA47) and $37 \mathrm{kDa}$ (PA37) (Fig. 1; Leppla, 1991) were prepared by limited digestion of PA (3-5 $\mathrm{mg} \mathrm{ml}^{-1}$ ) with chymotrypsin, type VII ( $N \alpha-p$-tosyl-Llysine chloromethyl ketone (TLCK)-treated, $125 \mu \mathrm{g}$ ), in $2 \cdot 3 \mathrm{mM}$ $\mathrm{NaH}_{2} \mathrm{PO}_{4}, 7.5 \mathrm{mM} \mathrm{Na} \mathrm{HPO}_{4}, 0.15 \mathrm{M} \mathrm{NaCl}, \mathrm{pH} 7 \cdot 3$ (PBS), for $10 \mathrm{~min}$ at room temperature. The reaction was stopped by adding PMSF and the sample was adjusted to $5 \mathrm{M}$ urea and $50 \mathrm{mM}$ HEPES. Chromatography was then performed on MonoS resin (Pharmacia-LKB) using $50 \mathrm{mM}$ HEPES, $5 \mathrm{M}$ urea buffer, $\mathrm{pH} 7 \cdot 55$. Fractions were eluted with a linear gradient of $0-0.5 \mathrm{M} \mathrm{NaCl}$ in $50 \mathrm{mM}$ HEPES, $5 \mathrm{M}$ urea buffer, $\mathrm{pH} 7.55$. Fragments were identified by SDS-PAGE. Urea present in the PA47 and PA37 fragments was lowered to $<0.5 \mathrm{M}$ by buffer exchange to $20 \mathrm{mM}$ HEPES, $50 \mathrm{mM} \mathrm{NaCl}$, pH 7.55, by using $30 \mathrm{kDa}$ cutoff membranes. Fragments were stored at $-70^{\circ} \mathrm{C}$.

To generate PA17 (Fig. 1), PA (3-5 mg ml${ }^{-1}$ ) was subjected to limited digestion with chymotrypsin, type VII $(125 \mu \mathrm{g})$ for $5 \mathrm{~min}$ followed by trypsin, type XIII $(12.5 \mu \mathrm{g})$ for $5 \mathrm{~min}$ on ice. The sample was adjusted to $5 \mathrm{M}$ urea and $50 \mathrm{mM}$ MES after adding PMSF. The digest was then chromatographed over MonoS resin using $50 \mathrm{mM}$ MES, $5 \mathrm{M}$ urea buffer, $\mathrm{pH} 6 \cdot 15$. Fractions were eluted with a linear gradient of $0-1 \mathrm{M} \mathrm{NaCl}$ in $50 \mathrm{mM}$ MES, $5 \mathrm{M}$ urea, $\mathrm{pH}$ 6.15. PA17 was identified by SDSPAGE. To ensure the removal of PA47 reactive fragments, the PA17 preparation was diluted fourfold in $5 \mathrm{mM} \mathrm{NaH}_{2} \mathrm{PO}_{4}$, $15 \mathrm{mM} \mathrm{Na}_{2} \mathrm{HPO}_{4}, 0.5 \mathrm{M} \mathrm{NaCl}, \mathrm{pH} 7 \cdot 0$, and passed four times over an immunoaffinity chromatography column containing rabbit anti-PA47 sera bound to hydrazide resin according to the manufacturer's instructions (Bio-Rad). The unbound PA17 pool was adjusted to $4 \mathrm{M}$ urea and the volume reduced by using a $10 \mathrm{kDa}$ cutoff membrane. Fragments were stored at $-70^{\circ} \mathrm{C}$.

Trypsin-treated PA (T-PA), chymotrypsin-treated PA (Ch-PA), chymotrypsin- and trypsin-treated PA (Ch/T-PA; Novak et al., 1992), and chymotrypsin-treated PA63 (Ch-PA63) were also prepared but without subsequent chromatography.

Hybridomas. Female BALB/c mice were immunized subcutaneously $(0.4 \mathrm{ml})$ and intraperitoneally $(0.2 \mathrm{ml})$ with purified PA63 (50 $\mu \mathrm{g})$ in Freund's complete adjuvant $(1: 1$; day 0$)$ or Freund's incomplete adjuvant (1:1; day 14). Subcutaneous injections were administered in two sites. On days 33 and 34, mice were injected both intravenously $(0.1 \mathrm{ml})$ and intraperitoneally $(0 \cdot 1 \mathrm{ml})$ with $100-200 \mu \mathrm{g}$ of PA63 in saline. Hybrid cell lines, prepared by fusing spleen cells with SP2/O-Ag14 myeloma cells (Earley \& Osterling, 1985), were screened by ELISA for PA63 reactivity. The preparation of ascites, quantification of Ig, and determination of antibody subclass were as described previously (Little et al., 1988).

Previously described mAbs produced against PA (Little et al., 1988) were also included in the analysis. Therefore, for identification purposes, the mAbs are designated with a subscript of the immunizing antigen: PA63 or PA.

Polyclonal antiserum. Fragments of PA, generated by limited proteolysis with chymotrypsin and trypsin (Novak et al., 1992), were separated on $20 \mathrm{~cm}$ SDS-PAGE gels $(12 \%$, w/v, acrylamide). The resolved protein bands were identified by staining with Pro-Green (Integrated Separation Systems) according to the manufacturer's instructions, excised, destained, rinsed in distilled water, and frozen at $-20^{\circ} \mathrm{C}$. Polyclonal rabbit antiserum against PA47 and PA17 was prepared by injecting the rabbits intramuscularly and subcutaneously with polyacrylamide gel slices that contained the respective fragment homogenized with adjuvant $(1: 1)$. The primary injection included Freund's complete adjuvant; all subsequent injections included Freund's incomplete adjuvant. Polyclonal antiserum against PA was produced in rabbits injected intramuscularly and subcutaneously with purified PA (100 $\mu \mathrm{g}$ protein) and Freund's complete or incomplete adjuvant as above.

ELISA and ELISA competition assay. The ELISA was as described previously (Little et al., 1990). Competition among $\mathrm{mAbs}$ for a single antigenic site was measured by using a competitive-binding ELISA (Little et al., 1988) with the following changes. Purified $m A$ bs were biotinylated by an $N$ hydroxysuccinimide derivative of biotin with an aminohexanoate spacer arm (Vector Laboratories). A 1:100 dilution of ascites $\mathrm{mAb}$ was used to determine the percentage of biotinylated $\mathrm{mAb}$ bound in the presence of competing, unlabelled $\mathrm{mAbs}$. The percentage binding was calculated from the following formula: percentage binding $=\left(A_{405}\right.$ test well $/ A_{405}$ control well) $\times 100$, where test wells contained biotinylated $\mathrm{mAb}$ plus competitor, and control wells contained diluent instead of competitor. Absorbance readings were obtained using a Bio-Tek model EL-310 autoreader.

Neutralization assay in rats. Neutralization of lethal toxin activity in vivo was assayed in male Fischer 344 rats (Little et al., 1988), which were injected intravenously with mixtures of $40 \mu \mathrm{g}$ PA plus $8 \mu \mathrm{g} \mathrm{LF}$ (approximately $13 \mathrm{LD}_{50}$; Ezzell et al., 1984), and ascitic fluid after preincubation for $1 \mathrm{~h}$ at $37^{\circ} \mathrm{C}$. Ascitic fluids that protected or delayed the death of rats were tested at lower concentrations until no protection was observed. All $\mathrm{mAbs}$ were tested for neutralizing ability in vivo.

Cellular neutralization assays. An in vitro colorimetric assay, developed to assess cell growth and viability (Green et al., 1984; Mosmann, 1983), was used as described previously (Little et al., 1990) to study the interactions between mAbs, PA, LF and J774A.1 murine macrophage cells. Briefly, the three different in vitro neutralization protocols were as follows. (i) $(\mathrm{PA}+\mathrm{LF}+\mathrm{mAb})$; ascitic fluid containing $\mathrm{mAb}$ was preincubated in lethal toxin ( $400 \mathrm{ng} \mathrm{PA} \mathrm{ml}^{-1}$ plus $40 \mathrm{ng} \mathrm{LF} \mathrm{ml}^{-1}$ ) for $1 \mathrm{~h}$ at $37^{\circ} \mathrm{C}$ before adding to J774A.1 cells. (ii) (PA + cell); J774A.1 cells were preincubated with PA $\left(400 \mathrm{ng} \mathrm{ml}^{-1}\right)$ at $4{ }^{\circ} \mathrm{C}$ for $2 \mathrm{~h}$. In separate 96-well plates, ascitic fluids containing $\mathrm{mAb}$ were preincubated in LF $\left(40 \mathrm{ng} \mathrm{ml}^{-1}\right)$ at $37^{\circ} \mathrm{C}$ for $1 \mathrm{~h}$. After aspirating the PA from the cells, $\mathrm{mAb}$ dilutions in $\mathrm{LF}$ were added. (iii) (PA + LF + cell); J774A.1 cells were washed twice in cold incubation medium and then were preincubated with PA $\left(800 \mathrm{ng} \mathrm{ml}^{-1}\right)$ and LF $\left(80 \mathrm{ng} \mathrm{ml}^{-1}\right)$ at $4{ }^{\circ} \mathrm{C}$ for $2 \mathrm{~h}$. After washing the cells twice with cold incubation medium, dilutions of ascitic fluids containing $\mathrm{mAb}$ were added. Only those $\mathrm{mAbs}$ that neutralized lethal toxin in the first protocol were tested in the last two protocols. Cell viability was calculated by using the average $A_{540}$ of pairs of wells receiving either toxin plus $\mathrm{mAb}$ or $\mathrm{mAb}$ alone. We chose the concentration of ascites $\operatorname{Ig}\left(\mu \mathrm{g} \mathrm{ml}^{-1}\right)$ that inhibited $80 \%$ of cell death as a quantitative measure of the 


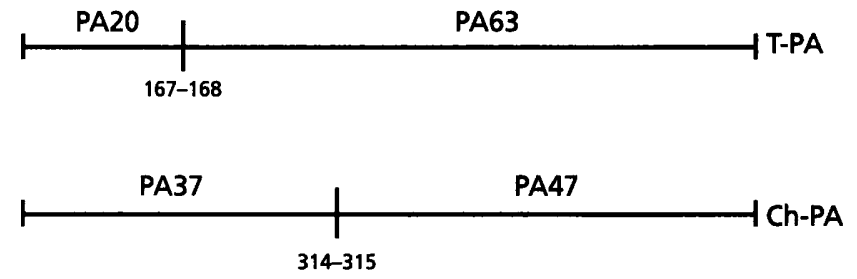

Fig. 1. Schematic representation of major protease-sensitive sites on PA and PA63 and fragments generated by limited proteolysis by trypsin (T-PA) or chymotrypsin (Ch-PA and (h-PA63). Amino acid residues are PA17 $\left.\right|_{314-315} \quad$ PA47 Ch-PA63 numbered from the $\mathrm{N}$-terminal glutamic acid of mature PA.

Table 1. Description of recombinant clones used in this study

\begin{tabular}{|llll|}
\hline $\begin{array}{l}\text { PA } \\
\text { deletion* }\end{array}$ & \multicolumn{1}{c}{$\begin{array}{c}\text { Mutant } \\
\text { plasmid }\end{array}$} & Expression host & \multicolumn{1}{c|}{ Source } \\
\hline PA-735 & pYS2 & E. coli BL-21 & Singh et al. (1989) \\
PA-735 & pYS5 & B. subtilis WB600 & Singh et al. (1989) \\
PA-728 & pYD17 & B. subtilis DB104 & Singh et al. (1991) \\
PA-721 & pYS10 & E. coli BL-21 & Singh et al. (1991) \\
PA-670 & pYD2 & B. subtilis WB600 & This study \\
PA-601 & pYD3 & B. subtilis WB600 & This study \\
PA-580 & pBKPPA465 & E. coli JM109 & Little \& Lowe (1991) \\
\hline
\end{tabular}

* PA deletions are designated according to the number of amino acid residues remaining of the original 735 amino acids.

in vitro neutralizing ability of the $\mathrm{mAb}$. Absorbance readings were obtained using a Bio-Tek model EL-310 autoreader.

Binding studies with ${ }^{125}$ I-PA. PA was iodinated by using the ${ }^{125}$ I-Bolton-Hunter reagent (Amersham) (specific activity $2.0 \times 10^{6}$ c.p.m. $\mu \mathrm{g}^{-1}$ to $5.0 \times 10^{6}$ c.p.m. $\left.\mu \mathrm{g}^{-1}\right)$. mAbs $(100 \mu \mathrm{g}$ ascites Ig ml $\left.{ }^{-1}\right)$ were preincubated with ${ }^{125} \mathrm{I}-\mathrm{PA}\left(0.075 \mu \mathrm{g} \mathrm{ml}^{-1}\right)$ for $2 \mathrm{~h}$ at $4{ }^{\circ} \mathrm{C}$ and added to $\mathrm{L} 6$ rat skeletal muscle myoblast cells in 24-well plates $\left(2 \times 10^{5}\right.$ to $\left.4 \times 10^{5} \mathrm{ml}^{-1}\right)$ previously washed with cold Hanks' balanced salt solution (HBSS). After incubating for $6 \mathrm{~h}$ at $4{ }^{\circ} \mathrm{C}$ on ice, the monolayers were washed three times with cold HBSS, solubilized by adding $0.75 \mathrm{ml} 0.1 \mathrm{M}$ $\mathrm{NaOH}$, and the radioactivity measured. Specific binding was determined by subtracting nonspecific background binding from total binding. Nonspecific binding, determined by adding 250 -fold excess of unlabelled PA in addition to ${ }^{125}$ I-PA, was less than $10 \%$ of total binding. Data are reported as percentage inhibition of the specific binding occurring in control wells incubated without $\mathrm{mAb}$. Assays were done in triplicate.

Binding studies with ${ }^{125}$ I-LF. Binding studies, with LF iodinated by the chloramine- $T$ method (specific activity $2.0 \times 10^{7}$ c.p.m. $\mu \mathrm{g}^{-1}$ to $3.0 \times 10^{7}$ c.p.m. $\mu \mathrm{g}^{-1}$ ), were based upon previously described methods (Little et al., 1990). L6 cells $\left(2 \times 10^{5}\right.$ to $\left.4 \times 10^{5} \mathrm{ml}^{-1}\right)$ were preincubated with $400 \mu \mathrm{l} \mathrm{PA}$ $\left(0.075 \mu \mathrm{g} \mathrm{ml}^{-1}\right)$ for $18 \mathrm{~h}$ at $4{ }^{\circ} \mathrm{C}$ on ice. Cells were washed with cold HBSS and then incubated with $400 \mu \mathrm{l}$ ascitic fluid containing $\mathrm{mAb}\left(100 \mu \mathrm{g} \mathrm{Ig} \mathrm{ml}{ }^{-1}\right)$ for $1 \mathrm{~h}$ at $4{ }^{\circ} \mathrm{C}$, followed by the addition of $20 \mu \mathrm{l}$ per well of ${ }^{125} \mathrm{I}$-LF (final concentration $50 \mathrm{ng} \mathrm{ml}^{-1}$ ). After incubating for $2 \mathrm{~h}$ at $4{ }^{\circ} \mathrm{C}$ on ice, monolayers were washed three times with cold HBSS, solubilized with $0.75 \mathrm{ml} 0.1 \mathrm{M} \mathrm{NaOH}$, and the mean count recorded from triplicate samples. Specific binding was determined by subtracting nonspecific binding from total binding. Nonspecific binding, determined by adding ${ }^{125} \mathrm{I}-\mathrm{LF}$ to cells in the absence of PA, was less than $15 \%$ of total binding. Data were reported as percentage inhibition of the specific binding occurring in control wells incubated without $\mathrm{mAb}$.

Immunoblot analysis of PA fragments. Fragments of PA, prepared by limited proteolysis with chymotrypsin $\left(125 \mu \mathrm{g} \mathrm{ml}^{-1}\right)$ or chymotrypsin $\left(125 \mu \mathrm{g} \mathrm{m}^{-1}\right)$ and trypsin $\left(12.5 \mu \mathrm{g} \mathrm{ml}^{-1}\right.$ ) (Novak et al., 1992), were separated by SDSPAGE under reducing conditions on $10 \%(\mathrm{w} / \mathrm{v})$ Tricine gels (Novex). Proteins were electrophoretically transferred to $0.2 \mu \mathrm{m}$ pore nitrocellulose (Towbin et al., 1979). The membranes were blocked with $5 \%$ (w/v) nonfat milk in $20 \mathrm{mM}$ Tris/ $\mathrm{HCl}, 0.5 \mathrm{M}$ $\mathrm{NaCl}, \mathrm{pH} 7.5$ (TBS) before incubation with antibodies diluted in TBS containing $5 \%$ milk and $0.05 \%$ Tween 20 . Membranes were washed with TBS containing $0.05 \%$ Tween 20 and then incubated with goat anti-mouse Igs conjugated to horseradish peroxidase (Kirkegaard \& Perry). An enhanced chemiluminescence method (ECL; Amersham) was used to detect reactive bands. Rabbit polyclonal antibodies were detected by using goat anti-rabbit IgG conjugated to horseradish peroxidase (Kirkegaard \& Perry).

Immunoblot analysis of PA expressed by recombinant clones. Recombinant clones used in this study are listed in Table 1. PA deletions are designated according to the number of amino acid residues remaining of the original 735 amino acids. Construction of Eschericbia coli JM109 cells containing pBKPPA 465 , a recombinant plasmid containing a deletion of 155 amino acids from the C-terminal coding region of the PA gene, pag, in pBluescript (KS+), was described previously (Little \& Lowe, 1991). Cells, harvested from cultures grown as described by Little \& Lowe (1991), were suspended in $25 \mathrm{mM}$ Tris/ $\mathrm{HCl}$ (pH 8.5), $100 \mathrm{mM} \mathrm{NaCl}, 30 \%$ (w/v) sucrose, $1 \mathrm{mM} \mathrm{PMSF}$, 
$1 \mathrm{mM}$ EDTA and $1 \mathrm{mM}$ 1,10-phenanthroline. Lysozyme $(300 \mu \mathrm{g}$ in $50 \mu \mathrm{l} 0.1 \mathrm{M}$ EDTA) was added and the cells were incubated on ice for $30 \mathrm{~min}$. The suspension was then centrifuged at $10000 \mathrm{~g}$ for $10 \mathrm{~min}$. The supernatant fluid was collected and analysed by SDS-PAGE on $10 \%$ Tricine gels (Novex). Separated proteins were electrophoretically transferred to $0.45 \mu \mathrm{m}$ nitrocellulose (Towbin et al., 1979), and membranes were developed as an immunoblot as described above for the PA fragments, using PBS buffers instead.

Construction of recombinant clones pYS2, pYD17 and pYS10, which express full-length pag, a 7-amino-acid deletion and a 14amino-acid deletion from the C-terminus of PA, respectively, was described previously (Singh et al., 1989, 1991). Protein from pYD17 was purified as described by Singh et al. (1991). Cells from $100 \mathrm{ml}$ cultures of pYS2 or pYS10, induced with IPTG,

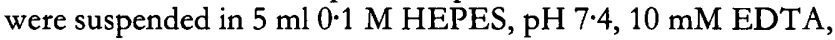
$5 \%(\mathrm{v} / \mathrm{v})$ heat-inactivated foetal bovine serum, $2 \%(\mathrm{v} / \mathrm{v})$ glycerol and $1 \mathrm{mM}$ 1,10-phenanthroline and sonicated in four $30 \mathrm{~s}$ intervals. Supernatants, collected after centrifugation for $15 \mathrm{~min}$ at $10000 \mathrm{~g}$, were purified on a mAb $10 \mathrm{G} 4_{\mathbf{p A}_{\mathrm{A}}}$ column. Protein was eluted with $2 \mathrm{M}$ sodium thiocyanate in $20 \mathrm{mM}$ HEPES, pH 7•4, after the column was washed with $40 \mathrm{ml}$ PBS. Eluted protein was subjected to SDS-PAGE after buffer exchange to $10 \mathrm{mM}$ HEPES, $\mathrm{pH} 7 \cdot 4$, electrophoretically transferred to nitrocellulose, and analysed in an immunoblot as above.

Recombinant plasmids pYD2 and pYD3, which express a 65and a 134-amino-acid deletion, respectively, from the $\mathrm{C}$ terminus of PA, were generated by PCR amplification of the native PA gene from pYS5 template (Singh et al., 1989). A nonmutagenic oligonucleotide primer, corresponding exactly to nucleotides 2842-2864 of pag (numbering system of Welkos et al., 1988), a region containing a Pst $\mathrm{I}$ recognition site unique to pag and pYS5, was used in all amplification reactions (Singh et al., 1991). Mutagenic oligonucleotide primers were designed to be complementary to the intended new $3^{\prime}$ end of the PA gene and to introduce two in-frame stop codons and a unique $\mathrm{Bam} \mathrm{HI}$ site. For pYD2 the primer for deleting nucleotides 3901-4095 was $5^{\prime}$ CATTATAT'TTTTTAAAATCTATAAATGGATCCTATTATTGCCGTAAACTAGAAATATTC $3^{\prime}$ and for pYD3 the primer for deleting nucleotides 3694-4095 was $5^{\prime}$ CTACTGACTCATCCGCCCCAGGATCCTATTAAT'TTC'TATCATAATGAAAACG 3'. Mutant constructs were confirmed by sequence analysis. Plasmids pYD2, pYD3 and pYS5 were transformed into Bacillus subtilis WB600 (Wu et al., 1991), which lacks six major extracellular proteases. Cultures were grown in brain heart infusion medium containing $5 \mu \mathrm{g}$ kanamycin sulfate $\mathrm{ml}^{-1}$ at $37^{\circ} \mathrm{C}$ for $6-8 \mathrm{~h}$ until the $\mathrm{OD}_{600}$ read $2 \cdot 2-2 \cdot 5$ using a Shimadzu UV160U spectrophotometer. The cultures were centrifuged at $10000 \mathrm{~g}$ and the supernatants were removed and supplemented to $1 \mathrm{mM}$ PMSF and $10 \mathrm{mM}$ EDTA. Supernatants were concentrated threefold with a Centriprep 30 device (Amicon) and analysed by immunoblot analysis after SDS-PAGE, as described above.

\section{RESULTS}

\section{In vivo neutralization of lethal toxin}

Two mAbs against PA neutralized lethal toxin activity $\left(13 \mathrm{LD}_{50}\right)$ in vivo. $\mathrm{mAbs} 1 \mathrm{G} 3_{\mathbf{P A 6 3}}$ and $10 \mathrm{E} 10_{\mathbf{P A 6 3}}$ protected $100 \%$ of animals (three of three) with $100 \mu \mathrm{g}$ and $1000 \mu \mathrm{g}$ ascites Ig, respectively.

The in vivo neutralizing ability of selected PA mAbs from an earlier study (Little et al., 1988) were recalculated as concentration of ascites Ig instead of ascites protein. $\mathrm{mAbs} 3 \mathrm{~B} 6_{\mathrm{PA}_{\mathrm{A}}}$ and $14 \mathrm{~B} 7_{\mathrm{PA}}$ protected rats with $926 \mu \mathrm{g}$ and $23 \mu \mathrm{g}$ of ascites $\mathrm{Ig}$, respectively. MAbs $2 \mathrm{D} 3_{\mathrm{PA}}$ and $2 \mathrm{D} 5_{\mathrm{PA}}$ delayed death by about $18 \mathrm{~h}$ with $1700 \mu \mathrm{g}$ and $1300 \mu \mathrm{g}$ of ascites Ig, respectively. No survival or delay of death was observed with mAbs $10 \mathrm{D} 2_{\mathrm{PA}}$ and $10 \mathrm{G} 4_{\mathrm{PA}}$, even at the highest concentrations tested, $1100 \mu \mathrm{g}$ and $923 \mu \mathrm{g}$ ascites $\mathrm{Ig}$, respectively.

\section{In vitro neutralization of lethal toxin}

To measure in vitro neutralization of lethal toxin cytolytic activity, mAbs developed in this study and those previously reported (Little et al., 1988) were tested by preincubating them with PA (400 $\mathrm{ng}$ ) and LF (40 ng) before adding them to J774A.1 cells [experiment (i), $\mathrm{PA}+\mathrm{LF}+\mathrm{mAb}$. Seven mAbs, at concentrations of $0.02-40 \mu \mathrm{g} \mathrm{Ig} \mathrm{ml}^{-1}$, neutralized in vitro lethal toxin cytolytic activity under these conditions (Table 2). One other $\mathrm{mAb}, 10 \mathrm{E} 10_{\mathbf{P A 6 3}}$, showed only weak neutralizing activity

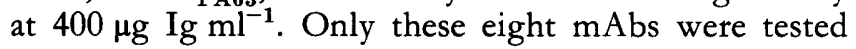
further.

Preincubating J774A.1 cells with PA, before adding mAb dilutions in LF [experiment (ii), PA + cells], demonstrated neutralization by five mAbs, $1 \mathrm{G} 3_{\mathrm{PA63}}, 2 \mathrm{D} 3_{\mathrm{PA}}$, $2 \mathrm{D} 5_{\mathbf{P A}}, 10 \mathrm{D} 2_{\mathbf{P A}}$ and $10 \mathrm{G} 4_{\mathrm{PA}}$ (Table 2). $\mathrm{mAbs} 3 \mathrm{~B} 6_{\mathbf{P A}}$, $14 \mathrm{~B} 7_{\mathbf{P A}}$ and $10 \mathrm{E} 10_{\mathbf{P A 6 3}}$ did not neutralize lethal toxin activity under these conditions (Table 2). When J774A.1 cells were preincubated with PA $\left(800 \mathrm{ng} \mathrm{ml}^{-1}\right)$ and LF ( $80 \mathrm{ng} \mathrm{ml}^{-1}$ ) before addition of mAbs [experiment (iii), $\mathrm{PA}+\mathrm{LF}+$ cells], five $\mathrm{mAbs}$ demonstrated only very weak neutralizing ability $\left(1 \mathrm{G} 3_{\mathrm{PA} 3}, 2 \mathrm{D} 3_{\mathrm{PA}}, 2 \mathrm{D} 5_{\mathrm{PA}}, 10 \mathrm{D} 2_{\mathrm{PA}}\right.$ and $10 \mathrm{G} 4_{\mathrm{PA}}$ ) (Table 2).

As shown in Table 2, two major groups of neutralizing activities were identified. The first group (1G3 $3_{\mathbf{P A 6 3}}$, $2 \mathrm{D} 3_{\mathrm{PA}}, 2 \mathrm{D} 5_{\mathrm{PA}_{\mathrm{A}}}, 10 \mathrm{D} 2_{\mathrm{PA}}$ and $\left.10 \mathrm{G} 4_{\mathrm{PA}}\right)$ neutralized lethal toxin cytolytic activity whether they were added before or after PA bound to cells. However, only mAb $1 G 3_{\text {PA63 }}$ was highly potent before and after PA bound to cells. The second group $\left(3 \mathrm{~B} 6_{\mathrm{PA}}, 14 \mathrm{~B} 7_{\mathrm{PA}}\right.$ and $\left.10 \mathrm{E} 10_{\mathrm{PA63}}\right)$ neutralized lethal toxin cytolytic activity only when combined with PA before being added to cells, and was inactive when added after PA had bound.

Seven of the $\mathrm{mAbs}$ were $\operatorname{IgG}_{1}$ and one was $\operatorname{IgG}_{2 \mathrm{~b}}$ subtype (Table 2).

\section{Inhibition of toxin formation on target cells}

Binding studies demonstrated that of the eight $\mathrm{mAbs}$ that neutralized lethal toxin cytolytic activity in the macrophage cytolysis assay, four, $1 \mathrm{G} 3_{\mathrm{PA} 63}, 2 \mathrm{D} 3_{\mathrm{PA}}, 2 \mathrm{D} 5_{\mathrm{PA}}$ and $10 \mathrm{D} 2_{\mathrm{PA}}$, inhibited binding of ${ }^{\mathbf{1 2 5}} \mathrm{I}-\mathrm{LF}$ to cell-bound PA by $78-102 \%$ (Table 3 ). $\mathrm{mAbs} 3 \mathrm{~B} 6_{\mathrm{PA}}, 14 \mathrm{~B} 7_{\mathbf{P A}}$ and $10 \mathrm{E} 10_{\mathrm{PA} 63}$ inhibited binding of ${ }^{\mathbf{1 2 5}} \mathrm{I}-\mathrm{PA}$ to the receptor by $90-98 \%$ (Table 3). mAb 10G4 $4_{\mathrm{PA}}$, which neutralized lethal toxin cytolytic activity only at high concentrations (Table 2), had only a modest effect on inhibition of binding of ${ }^{125} \mathrm{I}$ PA to the receptor and had no effect on binding of ${ }^{125} \mathrm{I}-\mathrm{LF}$ to cell-bound PA (Table 3). 
Table 2. Neutralizing activity of mAbs in cell-protection assays

The results are given as the concentration of ascites $\operatorname{IgG}\left(\mu \mathrm{g} \mathrm{ml}^{-1}\right)$ required to neutralize lethal toxin as measured at $80 \%$ of control wells. See Methods for description of each assay.

\begin{tabular}{|c|c|c|c|c|}
\hline \multirow[t]{2}{*}{$\mathbf{m A b}$} & \multirow{2}{*}{$\begin{array}{l}\text { Antibody } \\
\text { subtype }\end{array}$} & \multicolumn{3}{|c|}{ Cell-protection assay } \\
\hline & & $\begin{array}{c}\text { Expt (i) } \\
(\mathbf{P A}+\mathbf{L F}+\mathrm{mAb})\end{array}$ & $\begin{array}{c}\text { Expt (ii) } \\
\text { (PA + cells) }\end{array}$ & $\begin{array}{c}\text { Expt (iii) } \\
\text { (PA + LF + cells) }\end{array}$ \\
\hline $1 \mathrm{G} 3_{\mathrm{PA} 63}$ & $\mathrm{G}_{1}$ & 0.02 & 0.04 & 250 \\
\hline $2 \mathrm{D} 3_{\mathrm{PA}}$ & $\mathrm{G}_{1}{ }^{*}$ & $0 \cdot 1$ & 5 & 250 \\
\hline $2 \mathrm{D} 5_{\mathrm{PA}}$ & $\mathrm{G}_{1} *$ & 0.03 & 0.6 & 250 \\
\hline $10 \mathrm{D} 2_{\mathrm{PA}}$ & $\mathrm{G}_{1}{ }^{*}$ & $0 \cdot 1$ & 10 & 900 \\
\hline $10 \mathrm{G} 4_{\mathrm{PA}}$ & $\mathrm{G}_{1}{ }^{*}$ & 40 & 70 & 800 \\
\hline $3 B 6_{P_{A}}$ & $\mathrm{G}_{1}{ }^{*}$ & 12 & $>1000$ & $>1000$ \\
\hline $14 \mathrm{~B} 7_{\mathrm{PA}}$ & $\mathrm{G}_{1}^{*}$ & 2 & $>1000$ & $>1000$ \\
\hline $10 \mathrm{E} 10_{\mathrm{PA} 63}$ & $\mathrm{G}_{2 \mathrm{~b}}$ & 400 & $>1000$ & $>1000$ \\
\hline
\end{tabular}

* Antibody subtypes were reported previously (Little et al., 1988).

Table 3. Percentage binding inhibition for mAbs that neutralized lethal toxin activity

\begin{tabular}{|c|c|c|}
\hline \multirow[t]{2}{*}{$\mathbf{m A b}$} & \multicolumn{2}{|c|}{ Percentage binding inhibition } \\
\hline & ${ }^{125} \mathrm{I}-\mathrm{PA}$ to cell* & ${ }^{125}$ I-LF to PA $\dagger$ \\
\hline $1 \mathrm{G} 3_{\mathrm{PA} 63}$ & 7 & 102 \\
\hline $2 \mathrm{D} 3_{\mathrm{PA}}$ & 39 & 80 \\
\hline $2 \mathrm{D} 5_{\mathrm{PA}}$ & 38 & 78 \\
\hline $10 \mathrm{D} 2_{\mathrm{PA}}$ & 21 & 88 \\
\hline $10 \mathrm{G} 4_{\mathrm{PA}}$ & 54 & 3 \\
\hline $3 B 6_{P A}$ & $98 \ddagger$ & 1 \\
\hline $14 \mathrm{~B} 7_{\mathrm{PA}}$ & $95 \ddagger$ & -1 \\
\hline $10 \mathrm{E} 10_{\mathrm{PA} 63}$ & 90 & 20 \\
\hline
\end{tabular}

* Inhibition of binding of ${ }^{125} \mathrm{I}-\mathrm{PA}$ to L6 cells.

† Inhibition of binding of ${ }^{125}$ I-LF to PA bound on L6 cells.

$\ddagger$ These data were reported previously (Little et al., 1988).

\section{Competition between mAbs for antigenic sites}

A competitive-binding ELISA against $\mathrm{PA}_{63}$ antigen identified three separate antigenic groups among the neutralizing mAbs (Table 4). Two separate antigenic regions were recognized by $\mathrm{mAbs}$ that inhibited binding of ${ }^{125} \mathrm{I}-\mathrm{LF}$ to cell-bound PA, while mAbs that inhibited binding of ${ }^{125} \mathrm{I}-\mathrm{PA}$ to cells recognized a single antigenic region. $\mathrm{mAB} 10 \mathrm{G} 4_{\mathrm{PA}}$ recognized the same antigenic region as identified by $\mathrm{mAbs} 2 \mathrm{D} 3_{\mathrm{PA}}, 2 \mathrm{D} 5_{\mathrm{PA}}$ and $10 \mathrm{D} 2_{\mathrm{PA}}$.

\section{Location of antigenic region recognized by $\mathrm{mAb}$ $1 \mathbf{G 3}_{\text {PA63 }}$}

ELISA titration curves of $\mathrm{mAb} 1 \mathrm{G} 3_{\mathrm{PA63}}$ ascites against protease-treated preparations and selected fragments of PA demonstrated that this $\mathrm{mAb}$ reacted most strongly with PA63 and Ch-PA63, with lesser reactivity against PA and T-PA (Fig. 2). No other PA fragments were recognized by $\mathrm{mAb} 1 \mathrm{G} 3_{\mathrm{PA63}}$ ascites by ELISA. Immunoblots with $\mathrm{mAb} 1 \mathrm{G} 3_{\mathrm{PA} 63}$ demonstrated reactivity against proteolytic fragments PA37 and PA17 but not PA47 (Fig. 3 , lanes 1 and 2). Major fragments in these preparations were identified by rabbit polyclonal antiserum against PA (Fig. 3, lanes 3 and 4). The higher than expected apparent mass of the PA17 fragment was noted previously (Novak et al., 1992).

\section{Location of the antigenic region recognized by mAbs $2 D 3_{P^{\prime}}, 2 D 5_{P A}, 10 D 2_{P A}$ and $10 G 4_{P A}$}

ELISA titration curves of $\mathrm{mAb} 2 \mathrm{D} 3_{\mathrm{PA}}$ against selected fragments of PA showed that this $m A b$ recognized an antigenic region on the PA47 fragment (Fig. 4). Similar results were observed for $\mathrm{mAbs} 2 \mathrm{D} 5_{\mathrm{PA}}, 10 \mathrm{D} 2_{\mathrm{PA}}$ and ${ }_{10 G} 4_{P A}$ (data not shown). Immunoblot analysis with $\mathrm{mAb} 2 \mathrm{D} 3_{\mathrm{PA}}$ of fragments resulting from chymotrypsintreated or chymotrypsin- and trypsin-treated PA preparations separated by SDS-PAGE also demonstrated recognition of an epitope within the PA47 fragment (Fig. 5 , lanes 1 and 2). Similar results were observed for $\mathrm{mAbs}$ $2 \mathrm{D} 5_{\mathrm{PA}}, 10 \mathrm{D} 2_{\mathrm{PA}}$ and $10 \mathrm{G} 4_{\mathrm{PA}}$ (data not shown). Immunoblots developed with rabbit anti-PA17 antibody showed reactivity with the PA37 and PA17 fragments, which confirmed their presence in these preparations (Fig. 5, lanes 3 and 4).

Immunoblots of recombinant proteins expressing deletions of pag generated into the $\mathrm{C}$-terminal coding region of $\mathrm{PA}$ showed that $\mathrm{mAb} 2 \mathrm{D} 3_{\mathrm{PA}}$ recognized full-length $\mathrm{PA}$ produced by the parent clone pYS5 and deletions of 65 and 134 amino acids, PA-670 and PA-601, respectively (Fig. 6, lanes 1-3). However, $\mathrm{mAb} 2 \mathrm{D} 3_{\mathrm{PA}}$ did not recognize a deletion of 155 amino acids (PA-580; Fig. 6, lane 4). Similar results were observed with $\mathrm{mAbs} 2 \mathrm{D} 5_{\mathrm{PA}}$, $10 \mathrm{D} 22_{\mathrm{PA}}$ and $10 \mathrm{G} 4_{\mathrm{PA}}$ (data not shown). Immunoblots with 
Table 4. Competitive antibody-binding ELISA between biotinylated and unlabelled neutralizing mAbs for $\mathrm{PA}_{63}$ antigen

The results are shown as the percentage of biotinylated $\mathrm{mAb}$ bound in the presence of a saturating concentration of unlabelled $\mathrm{mAb}$. Determinant groups are identified by boxes. Subscript suffixes have been omitted.

\begin{tabular}{|c|c|c|c|c|c|c|c|c|}
\hline \multirow{2}{*}{$\begin{array}{l}\text { Unlabelled } \\
\text { mAb }\end{array}$} & \multicolumn{8}{|c|}{ Biotinylated mAb* } \\
\hline & 1G3 & 2D3 & 2D5 & 10D2 & $10 \mathrm{G} 4$ & 3B6 & 14B7 & 10E10 \\
\hline $1 G 3$ & 4 & 58 & 67 & 60 & 58 & 78 & 88 & 73 \\
\hline $2 \mathrm{D} 3$ & 22 & $\mathbf{0}$ & 3 & 0 & 0 & 103 & 84 & 66 \\
\hline 2D5 & 37 & 0 & 3 & 0 & 4 & 116 & 93 & 42 \\
\hline 10D2 & 52 & 2 & 5 & 0 & 10 & 89 & 84 & 70 \\
\hline 10G4 & 57 & 24 & 8 & 0 & $\mathbf{0}$ & 58 & 34 & 79 \\
\hline $3 \mathrm{~B} 6$ & 111 & 110 & 97 & 100 & 35 & 0 & 5 & 7 \\
\hline $14 \mathrm{~B} 7$ & 85 & 92 & 95 & 89 & 34 & 0 & 1 & 6 \\
\hline 10E10 & 100 & 68 & 49 & 56 & 44 & 0 & 1 & 2 \\
\hline
\end{tabular}

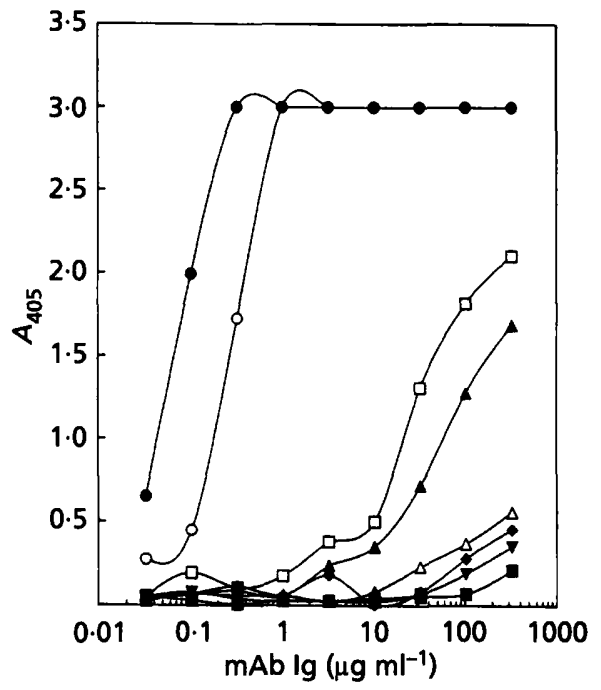

Fig. 2. ELISA titration curves of mAb $1 \mathrm{~GB}_{\mathrm{PA} 3}$. Serially diluted mAb was added to 96-well plates coated with PA ( $\mathbf{A})$, PA63 $(\mathbf{O}), \operatorname{PA} 47(\nabla)$, PA37 $(\bullet)$, PA17 $(\boldsymbol{\square})$, T-PA $(\square)$, Ch-PA $(\triangle)$ or ChPA63 (O).

rabbit polyclonal antiserum against $\mathrm{PA}$ identified $\mathrm{PA}$ produced by the deletion clones (Fig. 6, lanes 5-8). These results suggest that $\mathrm{mAbs} 2 \mathrm{D} 3_{\mathrm{PA}_{\mathrm{A}}}, 2 \mathrm{D} 5_{\mathrm{PA}}, 10 \mathrm{D} 2_{\mathrm{PA}}$ and $10 G 4_{\mathrm{PA}}$ recognized an epitope between amino acids Ile581 and Asn-601.

\section{Location of antigenic region recognized by $\mathrm{mAb}$ $3 B 6_{P A}, 14 B 7_{P A}$ and $10 E 10_{P A 6}$}

MAbs $3 \mathrm{~B} 6_{\mathrm{PA}_{1}}, 14 \mathrm{~B} 7_{\mathrm{PA}_{\mathrm{A}}}$ and $10 \mathrm{E} 10_{\mathrm{PA}_{63}}$ also recognized an antigenic region on the PA47 fragment, as demonstrated by similar titration curves and immunoblot results against proteolytic fragments of PA as $2 \mathrm{D} 3_{\mathrm{PA}}$ (data not shown).

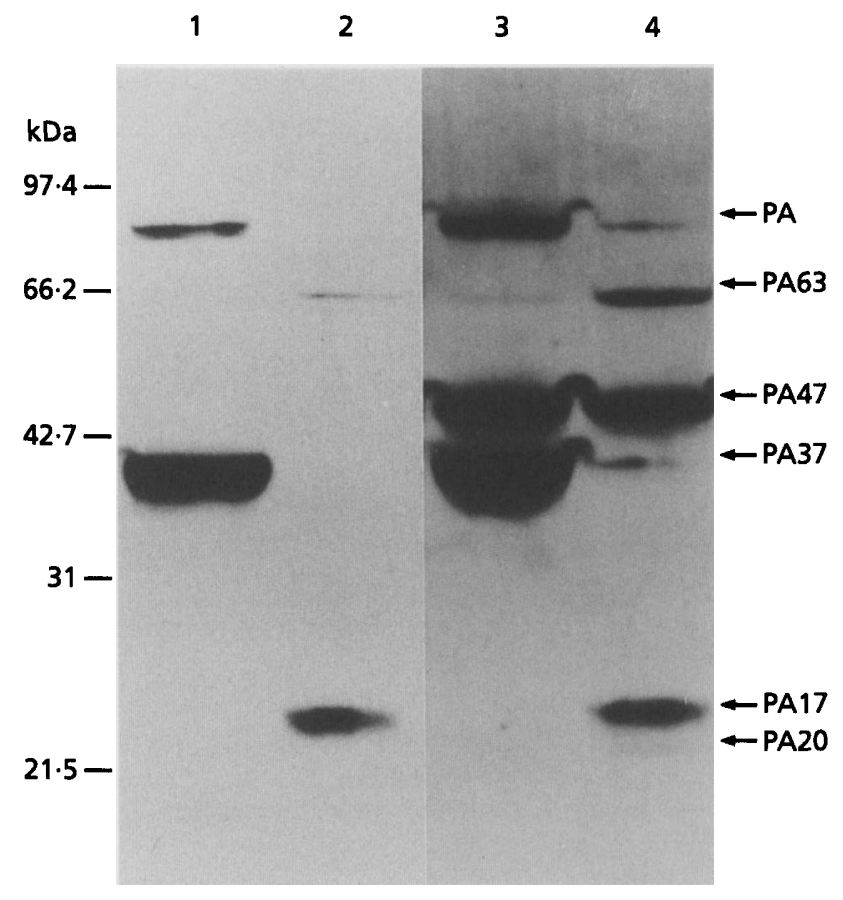

Fig. 3. Immunoblot analysis of fragments generated by limited proteolysis of PA with chymotrypsin or chymotrypsin and trypsin using $\mathrm{mAb} 1 \mathrm{G}_{\text {PAG3 }}$ (lanes 1 and 2) or rabbit polyclonal antiserum against PA (lanes 3 and 4). Samples were loaded as follows: Ch-PA, lanes 1 and 3; Ch/T-PA, lanes 2 and 4. Molecular mass markers are indicated on the left and the major fragments of PA are indicated on the right.

$\mathrm{mAb} 10 \mathrm{E} 10_{\text {PA63 }}$ did not recognize the recombinant protein expressed by deletion clone $\mathrm{PBKPPA} \Delta 65, \mathrm{PA}-580$ (data not shown), findings similar to $\mathrm{mAbs} 3 \mathrm{~B} 6_{\mathrm{PA}}$ and $14 B 7_{\mathrm{PA}}$ (Little \& Lowe, 1991) and $2 \mathrm{D} 3_{\mathrm{PA}}$ (Fig. 6). Immunoblots showed that $\mathrm{mAb} 3 \mathrm{~B} 6_{\mathbf{P A}}$ recognized PA735 (pYS2) and deletion clones PA-728 and PA-721 (Fig. 


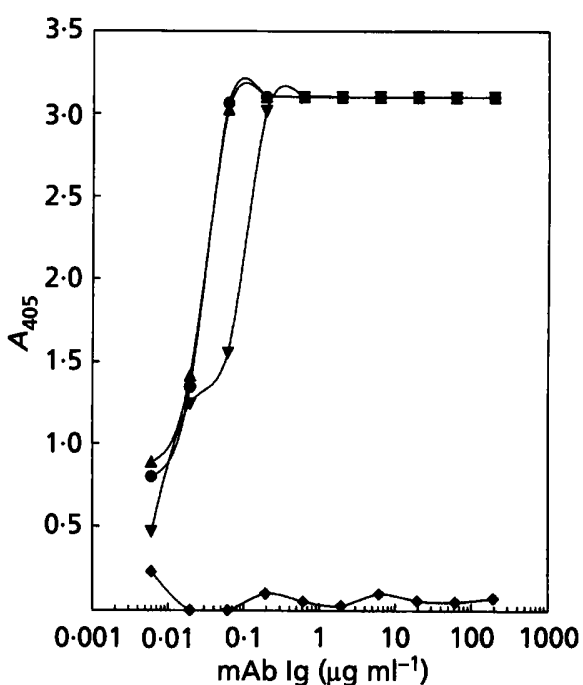

Fig. 4. ELISA titration curves of $\mathrm{mAb} 2 \mathrm{D} 3_{\mathrm{PA}}$. Serially diluted mAb was added to 96-well plates coated with PA (A), PA63 $(0)$, PA47 $(\nabla)$ or PA37 $(\diamond)$.

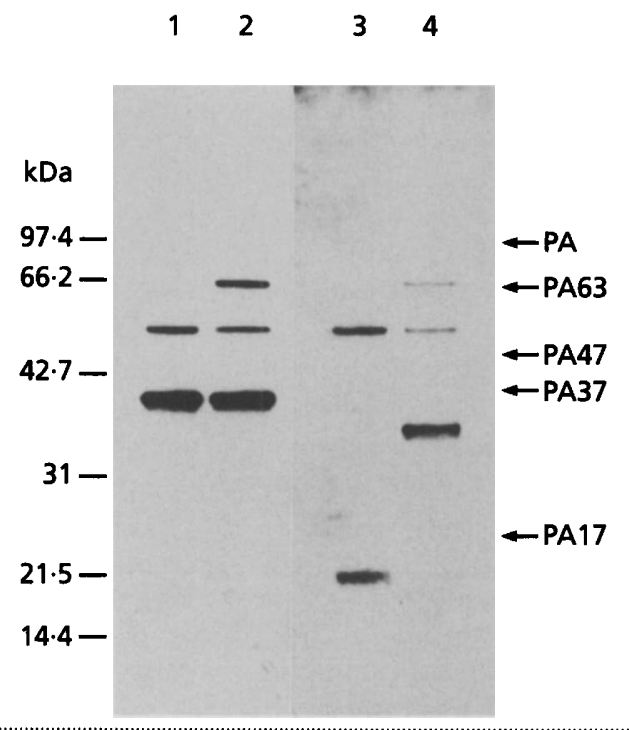

Fig. 5. Immunoblot analysis of fragments generated by limited proteolysis of PA with chymotrypsin or chymotrypsin and trypsin using mAb 2D3 ${ }_{P A}$ (lanes 1 and 2) or rabbit polyclonal serum against PA17 (lanes 3 and 4). Samples were loaded as follows: Ch/T-PA, lanes 1 and 3; Ch-PA, lanes 2 and 4. Molecular mass markers are indicated on the left and the major fragments of PA are indicated on the right.

7, lanes 1-3). $\mathrm{mAb} 3 \mathrm{~B} 6_{\mathrm{PA}}$ did not recognize deletion clone PA-670 (Fig. 7, lane 4). Similar results were observed with $\mathrm{mAbs} 14 \mathrm{~B} 7_{\mathrm{PA}}$ and $10 \mathrm{E} 10_{\mathrm{PA}_{63}}$ (data not shown). These results suggest that these $m A$ bs map between Asp-671 and Ile-721. Immunoblots with rabbit polyclonal antiserum against PA identified PA produced by the deletion clones (Fig. 7, lanes 5-8).

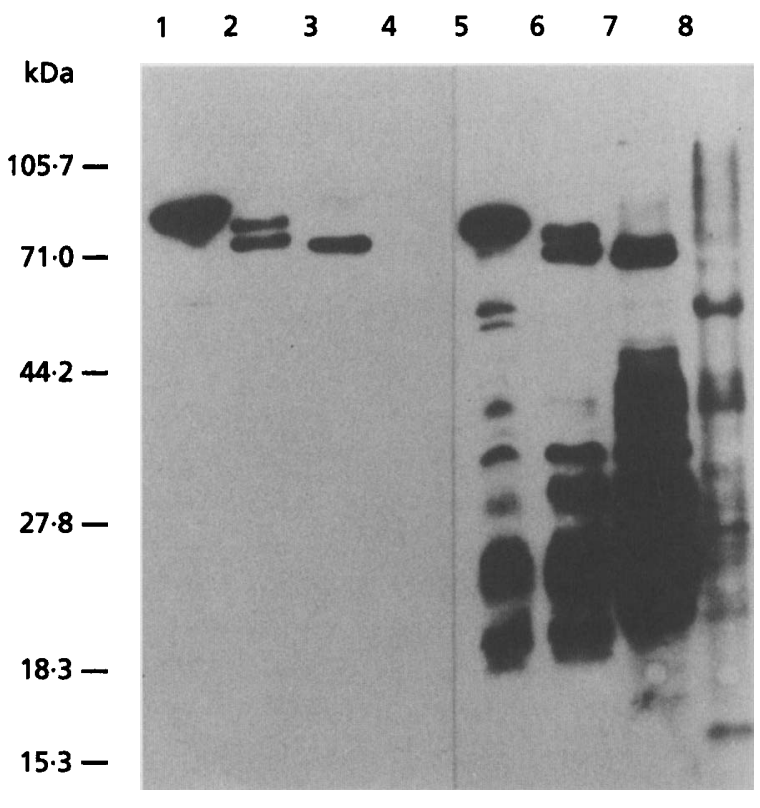

Fig. 6. Immunoblot analysis of PA recombinant proteins using $m A b 2 D 3_{P A}$ (lanes 1-4) or rabbit anti-PA polyclonal serum (lanes 5-8). Lanes 1 and 5, PA-735 (pYS5); lanes 2 and 6, PA-670; lanes 3 and 7, PA-601; lanes 4 and 8, PA-580. Molecular mass markers are indicated on the left.

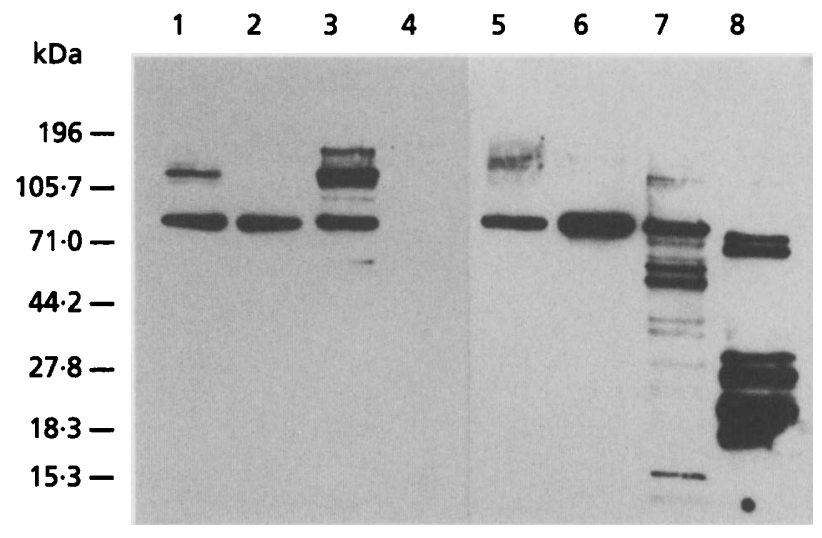

Fig. 7. Immunoblot analysis of PA recombinant proteins using mAb $3 B 6_{P A}$ (lanes 1-4) or rabbit anti-PA polyclonal serum (lanes 5-8). Lanes 1 and 5, PA-735 (pYS2); lanes 2 and 6, PA-728; lanes 3 and 7, PA-721; lanes 4 and 8, PA-670. Molecular mass markers are indicated on the left.

\section{DISCUSSION}

\section{Identification of antigenic region recognized by mAbs 3B6 ${ }_{\mathrm{PA}}, 14 \mathrm{~B} 7_{\mathrm{PA}}$ and $10 \mathrm{E} 10_{\mathrm{PA} 63}$}

The proposed model for the formation of lethal or oedema toxin from $B$. anthracis identifies regions of PA that interact with cell receptors, bind LF or EF, and translocate the toxin into the cytosol (Leppla, 1991). The extreme C-terminus of PA takes part in binding to cell receptors (Singh et al., 1991). We previously reported that $\mathrm{mAbs} 3 \mathrm{~B} 6_{\mathrm{PA}}$ and $14 \mathrm{~B} 7_{\mathrm{PA}}$ blocked binding of PA to cells 
(Little et al., 1988) and identified an antigenic region within the $155 \mathrm{C}$-terminal amino acids of PA (Little \& Lowe, 1991). The activities of $\mathrm{mAbs} 3 \mathrm{~B} 6_{\mathrm{PA}}, 14 \mathrm{~B} 7_{\mathbf{P A}}$ and $10 \mathrm{E} 10_{\mathbf{P A} 3}$ in the in vitro macrophage cytolysis assay provides additional indirect evidence that PA binding is required for toxin formation. This report further maps the antigenic region recognized by $m A$ bs that block the binding of PA to cells between amino acids Asp-671 and Ile-721. In contrast to an earlier report (Singh et al., 1991), the immunoblot reactivity we observed between these $\mathrm{mAbs}$ and the PA deletion proteins may have been due to a partial restoration of native conformations of the proteins or epitopes during electrophoretic transfer to nitrocellulose in the presence of Towbin buffer (Towbin et al., 1979), which lacks SDS.

\section{Identification of antigenic region recognized by mAbs 2D3 ${ }_{P_{A},} 2 D 5_{P A}$ and 10D2 $2_{P A}$}

Two different, non-competitive antigenic regions were defined with respect to location on PA63 by the competitive-binding ELISA and immunoblot analysis by mAbs that neutralized lethal toxin activity by inhibiting the binding of LF to cell-bound PA. One region, recognized by $m A b s 2 D 3_{P_{A}}, 2 D 5_{P A}$ and $10 \mathrm{D} 2_{\mathrm{PA}}$, resides within the PA47 fragment. Immunoblots of recombinant proteins expressing deletions of pag generated into the $C$ terminal coding region of PA demonstrated that these $\mathrm{mAbs}$ recognized an epitope between amino acids Ile-581 and Asn-601. mAb 10G4 $4_{\mathrm{PA}}$, which also mapped to the same region, was able to neutralize lethal toxin activity in vitro, probably due to steric hindrance effects, as it did not inhibit significantly the binding of ${ }^{125} \mathrm{I}-\mathrm{PA}$ to cells or ${ }^{125} \mathrm{I}$ LF to cell-bound PA. The absence of any interference between these $\mathrm{mAbs}$ and $\mathrm{mAbs}$ that block binding to cells, such as $3 \mathrm{~B} 6_{\mathrm{PA}}, 14 \mathrm{~B} 7_{\mathrm{PA}}$ and $10 \mathrm{E} 10_{\mathrm{PA} 33}$, in the competition ELISA, their inability to significantly block ${ }^{125}$ I-PA binding to the cell receptor, and their ability to neutralize lethal toxin activity in the macrophage cytolysis assay after PA was bound to cells suggest that the Cterminal portion of PA plays a role in interaction with cell receptors as well as with $\mathrm{LF}$. Although a successive loss of C-terminal amino acids demonstrated a corresponding decreased ability to bind to cell receptors, recombinant proteins with deletions of up to seven amino acids were able to bind LF or EF, similar to full-length PA (Singh et al., 1991). We have not yet evaluated the ability of recombinant proteins with deletions longer than 14 amino acids to interact with either LF or EF.

\section{Identification of antigenic region recognized by mAb $1 \mathrm{~GB}_{\text {PA63 }}$}

The second antigenic region recognized by $\mathrm{mAbs}$ that inhibited binding of ${ }^{125} \mathrm{I}$-LF to $\mathrm{PA}$ was defined by $\mathrm{mAb}$ $1 \mathrm{G} 3_{\text {PA63 }}$. This $\mathrm{mAb}$ appeared to be more directly involved in $\mathrm{LF}$ binding than the other non-competitive region represented by $2 \mathrm{D} 3_{\mathrm{PA}}, 2 \mathrm{D} 5_{\mathrm{PA}}$ and $10 \mathrm{D} 2_{\mathrm{PA}} \cdot \mathrm{mAb} 1 \mathrm{G} 3_{\mathrm{PA} 63}$ was at least 10 -fold more active in neutralizing toxin activity when added after PA bound to cells and completely blocked binding of ${ }^{125} \mathrm{I}-\mathrm{LF}$ to PA. The epitope recognized by $\mathrm{mAb} 1 \mathrm{G} 3_{\mathrm{PA63}}$ was identified on PA17 by immunoblot analysis. Reactivity of $\mathrm{mAb} 1 \mathrm{G} 3_{\mathrm{PA63}}$ with PA37 and PA17, however, was not confirmed by ELISA. The different results observed between the two assays may be explained by differences in the preparation of the fragments rather than in differences in immobilization interactions of the antigen on plastic or nitrocellulose (Brennand et al., 1986). The PA37 and PA17 fragments used in the ELISA were prepared in the presence of $5 \mathrm{M}$ urea ; upon removal of urea by buffer exchange or dilution, complete or proper refolding of the molecule or epitope may not have occurred. We also did not observe reactivity of $\mathrm{mAb} 1 \mathrm{G} 3_{\mathrm{PA} 33}$ to PA17 prepared in the presence of $5 \mathrm{M}$ urea and passively bound to nitrocellulose or polyvinylidene fluoride membranes which were analysed by immunoblotting (data not shown). The antigenic region recognized by $1 \mathrm{G} 3_{\mathrm{PA63}}$ on PA37 and PA17 may have been restored on immunoblots after SDS-PAGE during electrophoretic transfer in Towbin buffer, which lacks SDS.

ELISA reactivity of $\mathrm{mAb} 1 \mathrm{G} 3_{\mathrm{PA63}}$ against PA63 was $2 \cdot 5$ orders of magnitude greater than against PA or T-PA, suggesting that proteolysis and subsequent removal of the $\mathrm{N}$-terminal $20 \mathrm{kDa}$ fragment is required to expose the epitope recognized by this $\mathrm{mAb}$. $\mathrm{mAb} 1 \mathrm{G} 3_{\mathrm{PA63}}$ retained its reactivity against $\mathrm{Ch}-\mathrm{PA} 63$, suggesting that the chymotrypsin site is not part of its epitope. Any conformational changes resulting from the binding of antigen to plastic (Hollander \& Katchalski-Katzir, 1986) apparently did not expose the antigenic site(s) after proteolytic nicking of PA.

Whether these mAbs directly inhibit binding of PA to cells or of LF to cell-bound PA, or whether they do so indirectly, by steric hindrance or by causing a change in conformation of PA upon binding, is not known. If the inhibition is effected indirectly, the antigenic regions identified by these mAbs in this study may not accurately reflect the actual contact regions with the cell receptor or effector molecule, LF or EF. Identifying mAbs that neutralize lethal toxin activity will enable us to clarify the role of the toxins in pathogenesis as well as the role of antibodies in immunity, and to test their efficacy in protection against anthrax infection. Furthermore, specific knowledge of the binding site on PA for LF and EF suggests that PA fragments or peptides containing this site may be effective as vaccines against infection. Studies are presently under way to characterize further the antigenic regions recognized by these mAbs.

\section{Putative translocation region on PA not identified by mAbs}

In addition to binding to cells and binding LF or EF, PA is also postulated to contain a region required for translocation of the toxin (Leppla, 1991). The putative region for this activity has been associated with the chymotrypsin site, Phe-313 to Asp-315 (Novak et al., 1992, Singh et al., 1994). Lethal toxin constructed with PA previously treated with chymotrypsin (Novak et al., 1992) or mutated by altering the residues in this region (Singh $e t$ al., 1994), was nontoxic to cells. The ability of PA to bind to cell receptors and LF was not affected. In screening 
$\mathrm{mAbs}$ for this study, we did not identify any mAb that neutralized the cytolytic activity of lethal toxin without inhibiting binding of ${ }^{125} \mathrm{I}-\mathrm{PA}$ to cells or ${ }^{125} \mathrm{I}-\mathrm{LF}$ to cellbound PA.

\section{ACKNOWLEDGEMENTS}

We thank P. Merrill, R. K. Wolfskill, S. Byrd and S. Tobery, for technical assistance.

The views of the authors do not purport to reflect the positions of the Department of the Army or the Department of Defense.

\section{REFERENCES}

Beall, F. A., Taylor, M. J. \& Thorne, C. B. (1962). Rapid lethal effect in rats of a third component found upon fractionating the toxin of Bacillus antbracis. J Bacteriol 83, 1274-1280.

Bhatnagar, R., Singh, Y., Leppla, S. H. \& Friedlander, A. M. (1989). Calcium is required for the expression of anthrax lethal toxin activity in the macrophage-like cell line J774A.1. Infect Immun 57, 2107-2114.

Brennand, D. M., Danson, M. J. \& Hough, D. W. (1986). A comparison of ELISA screening methods for the production of monoclonal antibodies against soluble protein antigens. J Immunol Methods 93, 9-14.

Earley, E. M. \& Osterling, M. C. (1985). Fusion of mouse-mouse cells to produce hybridoma secreting monoclonal antibody. $J$ Tissue Cult Methods 9, 141-146.

Escuyer, V. \& Collier, R. J. (1991). Anthrax protective antigen interacts with a specific receptor on the surface of CHO-K1 cells. Infect Immun 59, 3381-3386.

Ezzell, J. W., Ivins, B. E. \& Leppla, S. H. (1984). Immunoelectrophoretic analysis, toxicity, and kinetics of in vitro production of the protective antigen and lethal factor components of Bacillus antbracis toxin. Infect Immun 45, 761-767.

Fish, D. C., Mahlandt, B. G., Dobbs, J. P. \& Lincoln, R. E. (1968). Purification and properties of in vitro-produced anthrax toxin components. J Bacteriol 95, 907-918.

Friedlander, A. M. (1986). Macrophages are sensitive to anthrax lethal toxin through an acid-dependent process. $J$ Biol Cbem 261, 7123-7126.

Gordon, V. M., Leppla, S. H. \& Hewlett, E. L. (1988). Inhibitors of receptor-mediated endocytosis block the entry of Bacillus antbracis adenylate cyclase toxin but not that of Bordetella pertussis adenylate cyclase toxin. Infect Immun 56, 1066-1069.

Green, L. M., Reade, J. L. \& Ware, C. F. (1984). Rapid colorimetric assay for cell viability: application to the quantitation of cytotoxic and growth inhibitory lymphokines. JImmunol Methods 70, 257-268.

Hollander, Z. \& Katchalski-Katzir, E. (1986). Use of monoclonal antibodies to detect conformational alterations in lactate dehydrogenase isoenzyme 5 on heat denaturation and on adsorption to polystyrene plates. Mol Immunol 23, 927-933.

Klimpel, K. R., Arora, N. \& Leppla, S. H. (1994). Anthrax toxin lethal factor contains a zinc metalloprotease consensus sequence which is required for lethal toxin activity. Mol Microbiol 13, 1093-1100.

Kochi, S. K., Schiavo, G., Mock, M. \& Montecucco, C. (1994). Zinc content of the Bacillus anthracis lethal factor. FEMS Microbiol Lett 124, 343-348.

Leppla, S. H. (1982). Anthrax toxin edema factor: a bacterial adenylate cyclase that increases cyclic AMP concentrations of eukaryotic cells Proc Natl Acad Sci US A 79, 3162-3166.
Leppla, S. H (1988). Production and purification of anthrax toxin. Methods Enzymol 165, 103-116.

Leppla, S. H. (1991). The anthrax toxin complex. In Sourcebook of Bacterial Protein Toxins, pp. 277-302. Edited by J. E. Alouf \& J. H. Freer. New York: Academic Press.

Leppla, S. H., Friedlander, A. M. \& Cora, E. M. (1987). Proteolytic activation of anthrax toxin bound to cellular receptors. In Bacterial Protein Toxins, pp. 111-112. Edited by F. Fehrenbach, J. E. Alouf, P. Falmagne, W. Goebel, J. Jeljaszewicz, D. Jurgens \& R. Rappuoli. Stuttgart: Gustav Fischer.

Leppla, S. H., Friedlander, A. M., Singh, Y., Cora, E. M. \& Bhatnagar, R. (1990). A model for anthrax toxic action at the cellular level. Salisbury Med Bull 68, 41-43.

Little, S. F. \& Lowe, J. R. (1991). Location of receptor-binding region of protective antigen from Bacillus anthracis. Biochem Biophys Res Commun 180, 531-537.

Little, S. F., Leppla, S. H. \& Cora, E. (1988). Production and characterization of monoclonal antibodies to the protective antigen component of Bacillus antbracis toxin. Infect Immun 56, 1807-1813.

Little, S. F., Leppla, S. H. \& Friedlander, A. M. (1990). Production and characterization of monoclonal antibodies against the lethal factor component of Bacillus antbracis lethal toxin. Infect Immun 58, 1606-1613.

Milne, J. C., Furlong, D. Hanna, P. C., Wall, J. S. \& Collier, R. J. (1994). Anthrax protective antigen forms oligomers during intoxication of mammalian cells. J Biol Chem 269, 20607-20612.

Mosmann, T. (1983). Rapid colorimetric assay for cellular growth and survival: application to proliferation and cytotoxicity assays. $J$ Immunol Methods 65, 55-63.

Novak, J. M., Stein, M.-P., Little, S. F., Leppla, S. H. \& Friedlander, A. M. (1992). Functional characterization of protease-treated Bacillus antbracis protective antigen. J Biol Chem 267, 17186-17193.

Singh, Y., Chaudhary, V. K. \& Leppla, S. H. (1989). A deleted variant of Bacillus anthracis protective antigen is non-toxic and blocks anthrax toxin action in vivo. J Biol Chem 264, 19103-19107.

Singh, Y., Klimpel, K. R., Quinn, C. P., Chaudhary, V. K. \& Leppla, S. H. (1991). The carboxyl-terminal end of protective antigen is required for receptor binding and anthrax toxin activity. $J$ Biol Chem 266, 15493-15497.

Singh, Y., Klimpel, K. R., Arora, N, Sharma, M. \& Leppla, S. H. (1994). The chymotrypsin-sensitive site, $\mathrm{FFD}^{315}$, in anthrax toxin protective antigen is required for translocation of lethal factor. $J$ Biol Chem 269, 29039-29046.

Stanley, J. L. \& Smith, H. (1961). Purification of factor I and recognition of a third factor of the anthrax toxin. J Gen Microbiol 26, 49-66.

Towbin, H., Staehelin, T. \& Gordon, J. (1979). Electrophoretic transfer of proteins from polyacrylamide gels to nitrocellulose sheets: procedure and some applications. Proc Natl Acad Sci USA 76, 4350-4354.

Welkos, S. L., Lowe, J.R., Eden-McCutchan, F., Vodkin, M., Leppla, S. H. \& Schmidt, J. J. (1988). Sequence and analysis of the DNA encoding protective antigen of Bacillus antbracis. Gene 69, 287-300.

Wu, X. C., Lee, W., Tran, L. \& Wong, S. L. (1991). Engineering a Bacillus subtilis expression-secretion system with a strain deficient in six extracellular proteases. J Bacteriol 173, 4952-4958.

Received 31 July 1995; revised 10 October 1995; accepted 19 October 1995. 